\title{
The Urban Plan of Venta Icenorum and its Relationship with the Boudican Revolt
}

\author{
By WILLIAM BOWDEN
}

\begin{abstract}
The idea that the town of Venta Icenorum (Caistor-by-Norwich) was laid out in the early Flavian period, as part of the Roman reaction to the Boudican revolt, has become canonical in literature on Roman Britain. Drawing on the results of recent excavations, this paper re-evaluates the evidence relating to the establishment of the street grid and questions the idea that the town reflects a coherent act of urban planning. It concludes by arguing that previous interpretations of the site within a 'Boudican' paradigm are fundamentally flawed.
\end{abstract}

Keywords: Venta Icenorum; Caistor-by-Norwich; Roman town; street grid; dating evidence; Boudican revolt; Donald Atkinson; Sheppard Frere

\section{INTRODUCTION}

$\mathrm{T}$ he name Venta Icenorum appears in the Antonine Itinerary although Ptolemy refers to Venta as a polis of the Iceni. ${ }^{1}$ The Ad Taum of the Peutinger Table may refer to Venta Icenorum, while the name of the town also appears in the Ravenna Cosmography (compiled c. A.D. 700). ${ }^{2}$ William Camden was the first to identify the walled Roman site at Caistor St Edmund, some $3 \mathrm{~km}$ to the south of Norwich (FIG. 1), as that of Venta Icenorum. He formed this opinion as early as 1579 , evidenced by a letter to the great Flemish cartographer Abraham Ortellius in which he writes that 'the Urbs Roma coin was found near Norwich in a place called Caster, where extensive remains of walls and many evidences of ancient times are to be seen and which I think is "Venta Icenorum", namely the city which Ptolemy calls "Venta Simenorum". 3 William Arderon (1749) and William Wilkins (1796) gave extensive descriptions of the remains at Caistor, which included measured drawings of the site. ${ }^{4}$ The site

Iter V Antonine Itinerary 474.6; Iter IX Antonine Itinerary 479.10; Ptolemy, Geography 2.3.11.

Rivet and Smith 1979, 492.

Leng 1967, 150.

Arderon 1749; Wilkins 1796. 


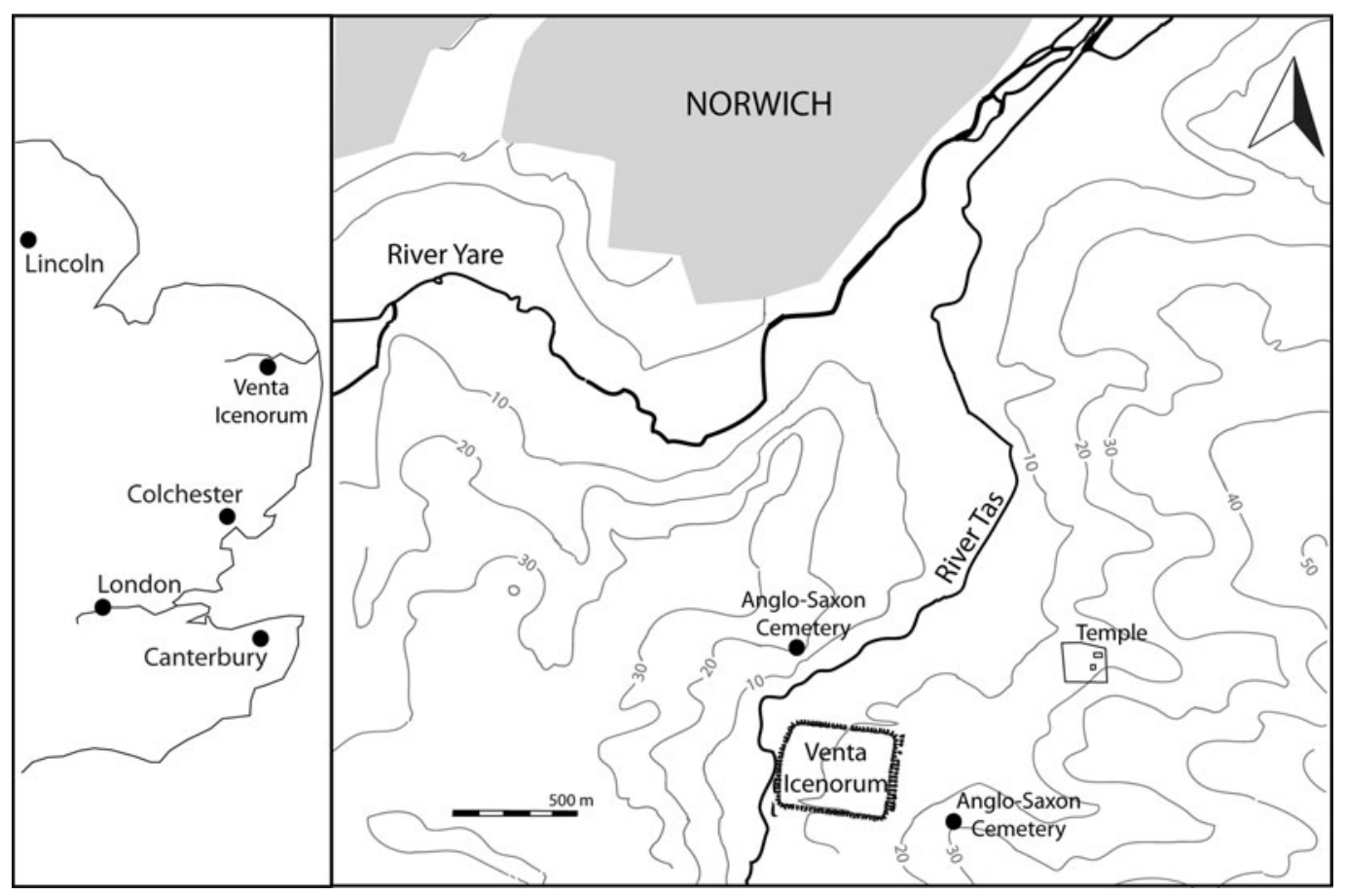

FIG. 1. The location of Venta Icenorum. (Drawn by William Bowden)

attracted relatively little attention during the nineteenth century, however, with many local antiquarians convinced that the Venta Icenorum of the textual sources was in fact on the site of the current city of Norwich. ${ }^{5}$

During the exceptionally dry summer of 1928, the streets of the Roman site at Caistor were revealed with remarkable clarity as parch-marks in the barley crop then growing on the site. This phenomenon was captured by an RAF pilot in a series of iconic aerial photographs that were published in Antiquity the following year (FIG. 2) and also in the Times and the Eastern Daily Press. ${ }^{6}$ The photographs caused tremendous excitement and, despite Mortimer Wheeler's calls for restraint, an excavation committee was established by the Norfolk and Norwich Archaeological Society. A public appeal for funds raised $£ 820$ (equivalent to around $£ 28,000$ in 2011) and the excavation committee appointed Donald Atkinson of Manchester University to direct the excavations. Atkinson had previously excavated at Wroxeter and was known in Norfolk through his excavations on the villa at Gayton Thorpe near Kings Lynn.

Atkinson carried out excavations between 1929 and 1935, investigating a series of the most visible crop-marks. Buildings excavated included two temples and an adjacent building, a bath-house, the forum and basilica, a 'house' and a series of pottery kilns, and the south gate. Only the 1929 excavations of the temples and the 1930 excavations of the kilns were published in any detail during Atkinson's lifetime with the remainder published by Sheppard Frere, working from Atkinson's often unsatisfactory records. ${ }^{7}$

Kent 1930.

Wheeler 1929. See also Bowden and Bescoby 2008.

Atkinson 1931; 1932; 1937; Frere 1971; 2005. 


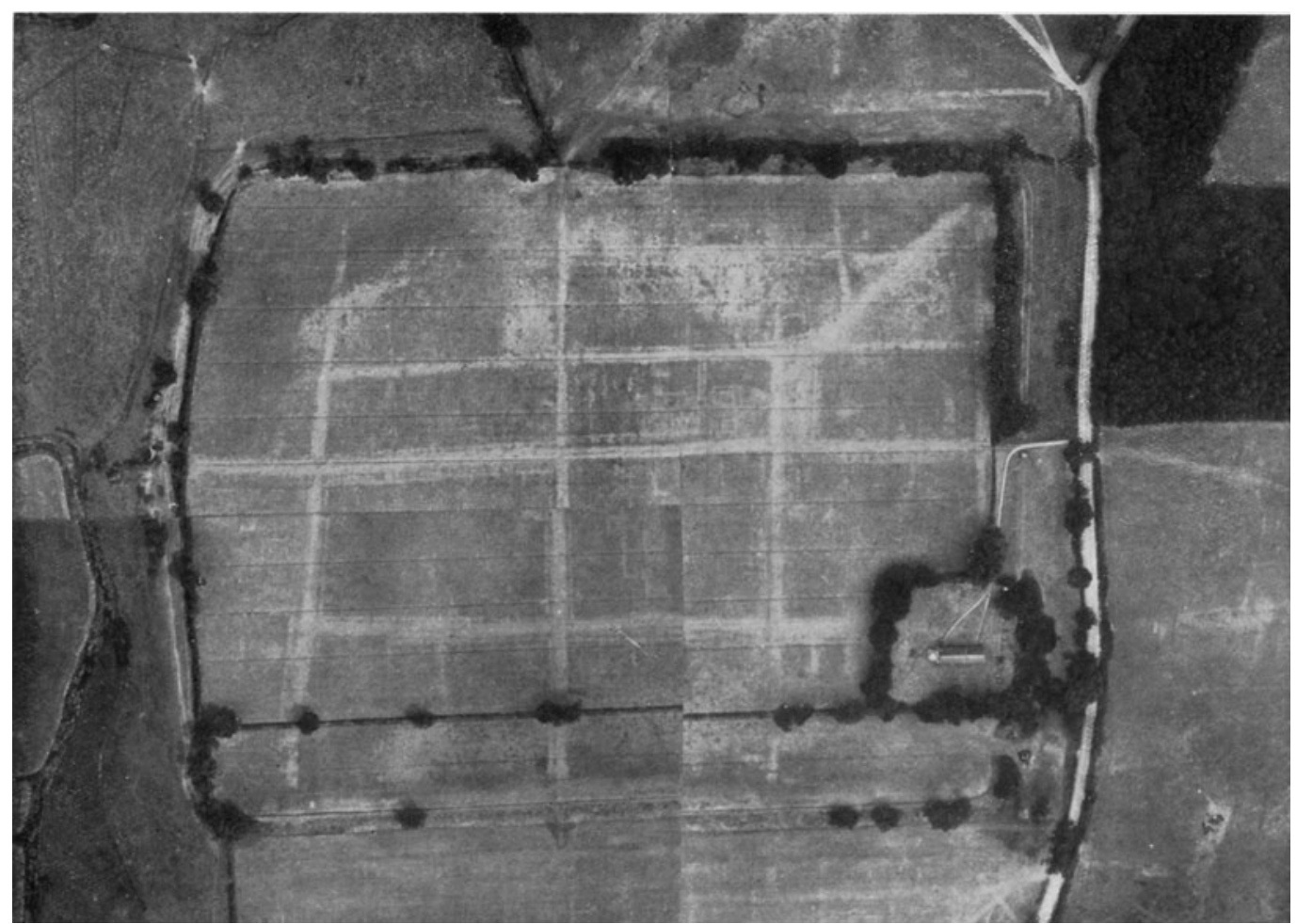

FIG. 2. The 1928 aerial photograph as published in Antiquity. (C English Heritage Crown copyright, Crawford Collection)

Atkinson's preliminary conclusions from his excavations in 1929, which he subsequently repeated with little variation, were that the town was founded and the streets laid out in the A.D. 70s as part of the Roman response to the Boudican uprising. ${ }^{8}$ These conclusions (discussed in detail below) have since been repeated in most discussions of the site. However, since 2006, Venta Icenorum has been the subject of investigations by the author, involving geophysical survey, trial excavation, geoarchaeology, field survey and re-evaluation of Atkinson's results. The preliminary results of this work suggest that many of our assumptions regarding the origins of the town need to be reassessed. ${ }^{9}$ This paper will focus on the evidence for the dating of the street grid and the idea that the town was laid out in a single operation as a coherent piece of urban planning.

\section{THE PLAN OF VENTA ICENORUM'S STREETS}

Before looking in detail at the dating of the streets, it is worth noting something of the history of their study. The evidence for the town plan of Venta Icenorum comes from aerial photographs and more recently from the Caistor Project's campaigns of geophysical survey. The original 1928

\footnotetext{
$8 \quad$ Atkinson 1931, 133.

9 The arguments relating to the possible Iron Age origins of Caistor and the question of a military base preceding the town are clearly fundamental to the debate regarding the town's foundation, but for reasons of space those questions will not be addressed here.
} 


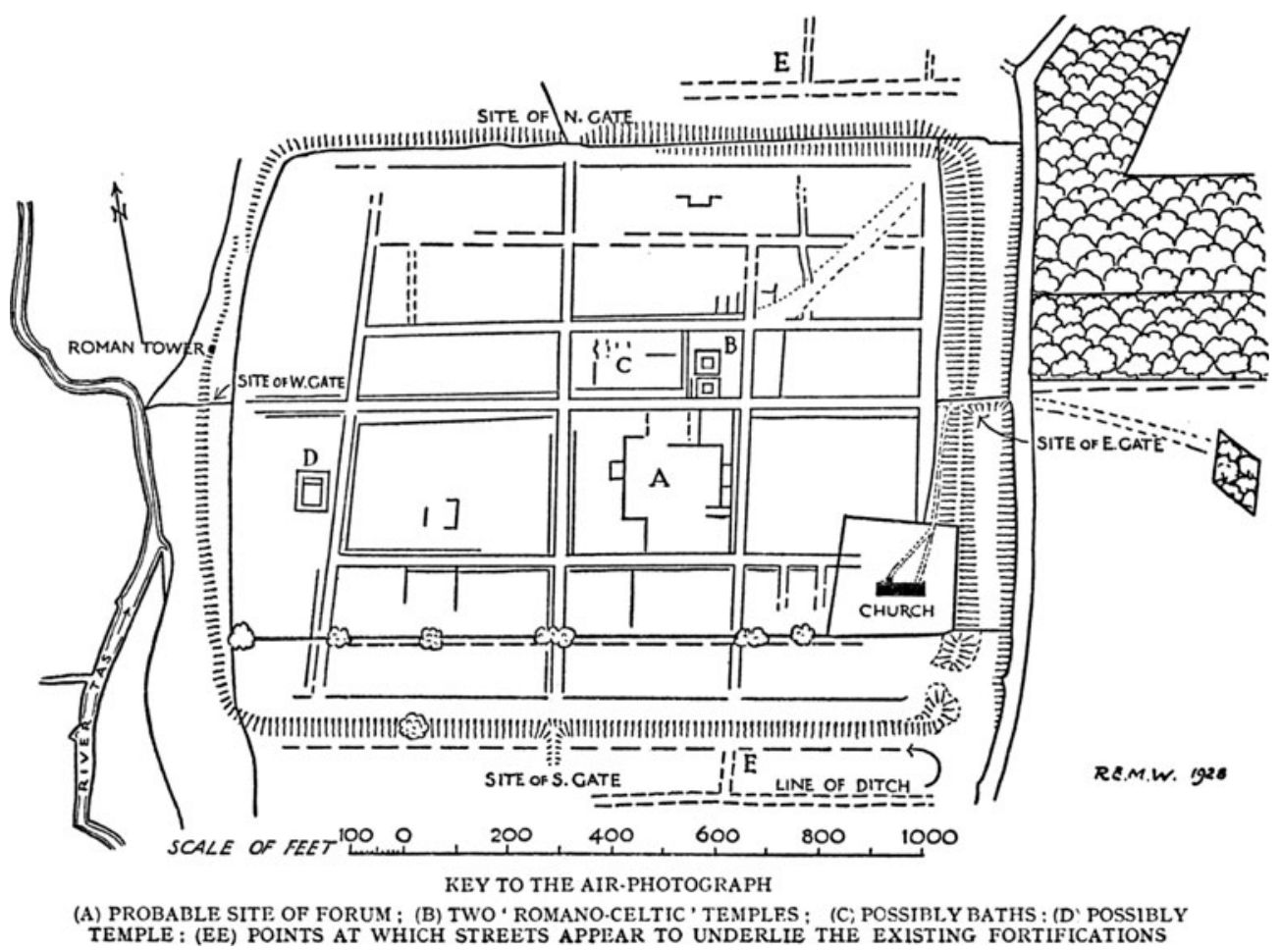

FIG. 3. Mortimer Wheeler's interpretative plan that accompanied the Antiquity publication. (By permission of Antiquity Publications Ltd)

aerial photographs demonstrated that the streets extended beyond the walled circuit on the north, south and east sides, a point that was noted by most subsequent commentators. The plan of the town drawn up by Wheeler (FIG. 3) in his commentary on the aerial photograph remained the definitive plan until 1971, when Frere published the first of his reports on Atkinson's excavations. Frere's revised plan (FIG. 4) was partly derived from Wheeler and partly from his attempts to fit Atkinson's excavation plans onto the aerial photograph. Frere's plan was, in turn, used as the basis for the Norfolk Archaeological Trust's 1992 plan of the site (FIG. 5), which has replaced Frere's plan as the standard depiction of the site. ${ }^{10}$

Although they vary in detail, all the published plans include a number of features in common. All depict an east-west street in the south of the walled area (dividing Frere's Insulae VI and XXI, XI and XX, XV and XIX, XVII and XVIII), which the recent geophysical survey has demonstrated to be a ploughed-out hedge-line. This seems to be part of a subconscious regularising of the site, since it created a line of half insulae (VI, XI, XV) mirroring a similar line of half insulae (IV, IX and XIII) to the north of the main east-west axial street. ${ }^{11}$

10 Wheeler's plan was reproduced, for example, in Hawkes 1949. Frere's (1971) plan was used in Wacher 1974, although it was replaced by the Trust's 1992 plan in the 1995 edition of the same volume. Frere himself favoured the Trust's plan in his recent publication of Atkinson's South Gate excavations (Frere 2005). See Bowden and Bescoby 2008 for detailed discussion of this issue.

11 Wilson (2003) does not repeat this error. 


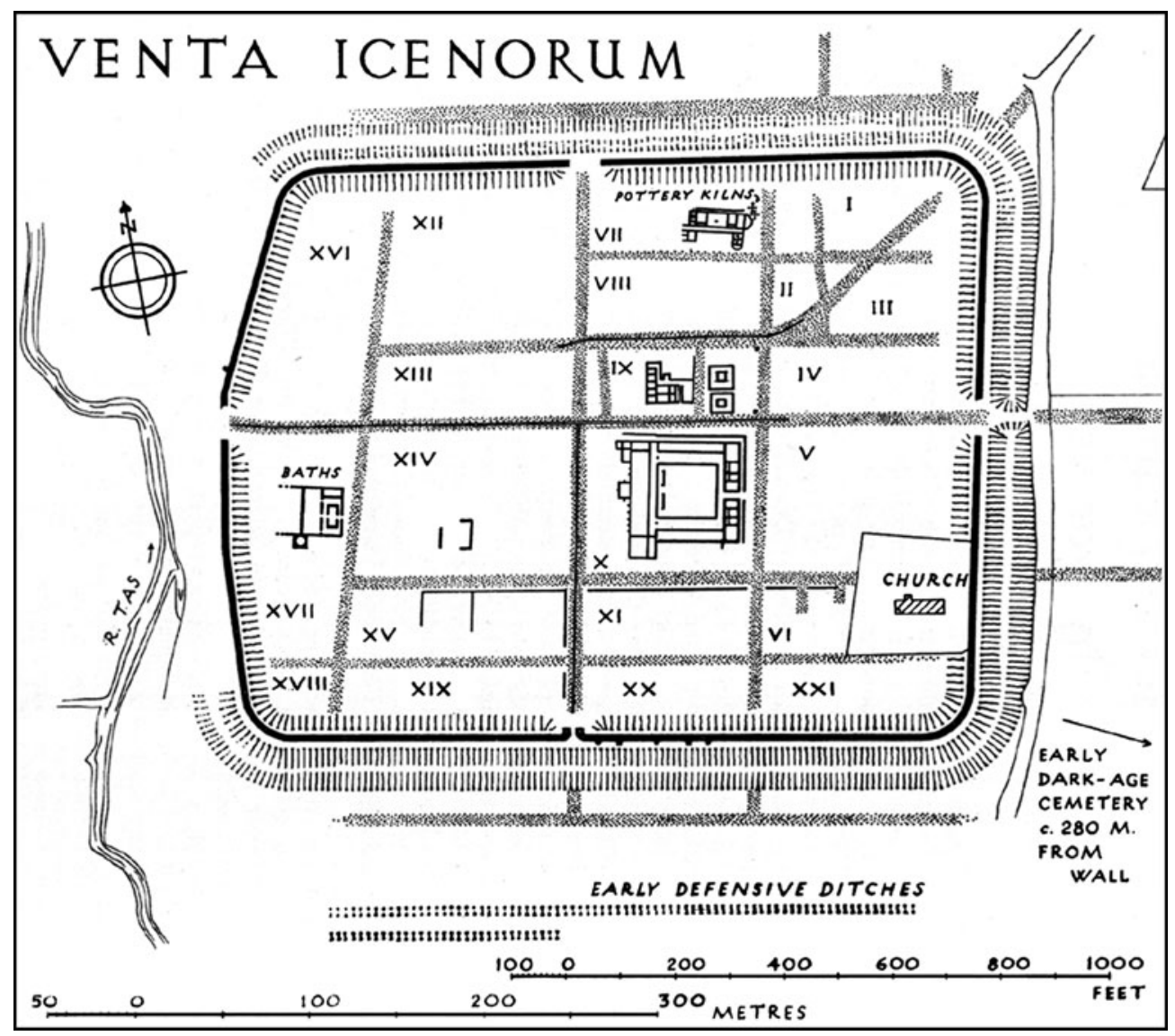

FIG. 4. Sheppard Frere's 1971 plan of Caistor. (By permission of S.S. Frere)

Through successive redrawing the streets have become progressively straighter. Frere himself noted that Atkinson's site plans depict the streets to the north and east of the forum as meeting at 90 degrees rather than the 88 degrees that Frere extrapolated from the aerial photographs. Equally, all the plans included the town walls, notwithstanding the fact that these were a later addition and are anachronistic in any depiction of the town before the third century. The result is a series of graphic depictions of the town in which it appears more planned and regimented than the evidence actually suggests, although it should be remembered that none of these plans were intended to be more than schematic representations of the site.

The geophysical survey of the town (FIGS 6-7) has demonstrated that the street grid is much less regular than the published plans suggest. ${ }^{12}$ The streets vary in width and the alignments of some have clearly shifted over time. Similarly the varying strength of geophysical anomalies suggests that the streets have different depths of gravel surfaces associated with them, with those that were resurfaced more frequently appearing as darker (weaker) magnetic responses, an issue that is discussed below. 


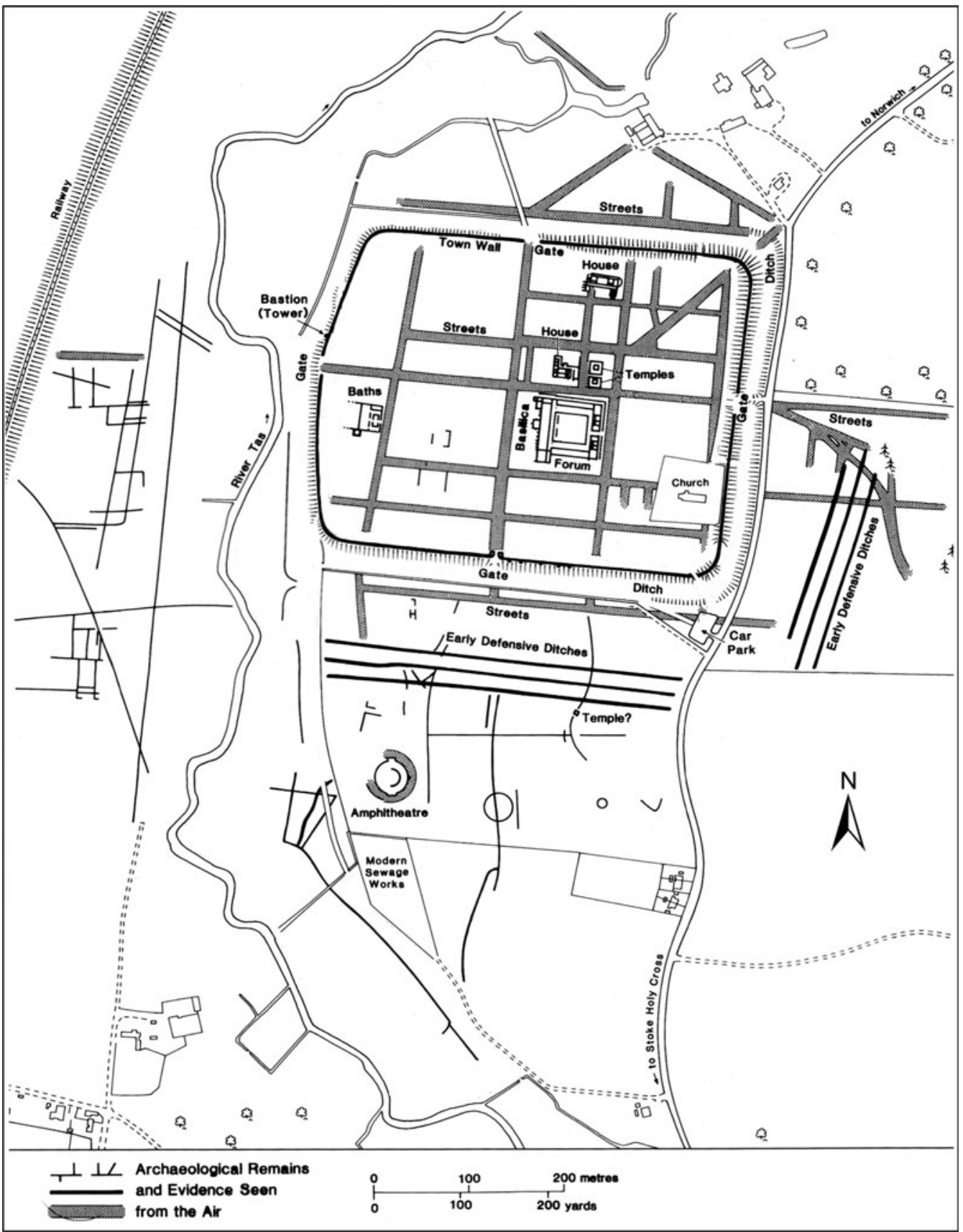

FIG. 5. The Norfolk Archaeological Trust's plan of the site. (By permission of Norfolk Archaeological Trust) 


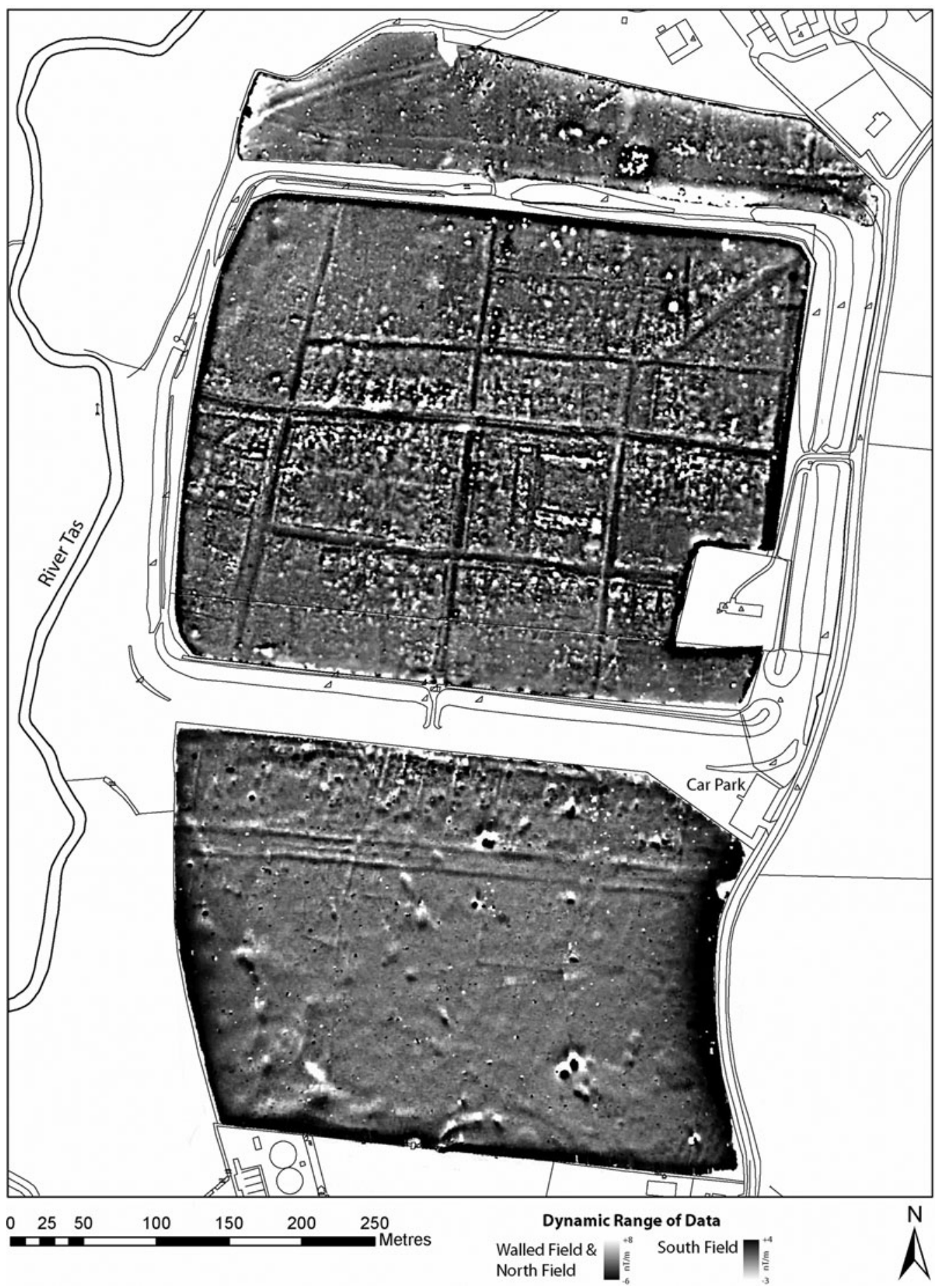

FIG. 6. Geophysical survey of the town and the fields to the north and south. (C) D. Bescoby) 


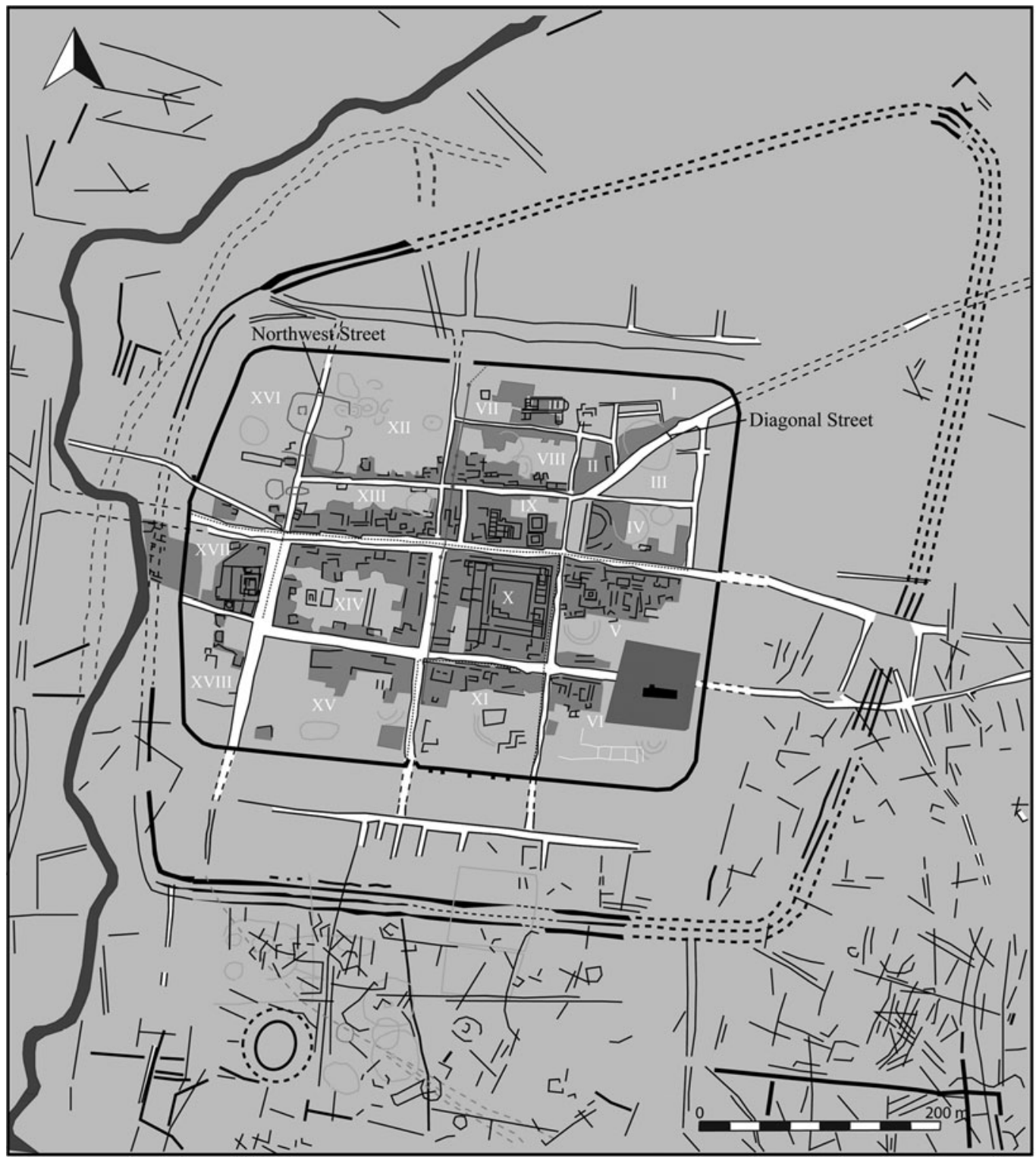

FIG. 7. Interpretative plan of the geophysical survey incorporating data from Donald Atkinson's excavations and some data from the National Mapping Programme survey of cropmarks (NMP data Copyright English Heritage National Mapping Programme, licensed to Norfolk County Council; drawn by William Bowden)

The evidence of the geophysical survey clearly indicates the significance of the main eastwest axial street on which most of the masonry buildings are concentrated, including the known public buildings of the town. Occupation seemingly becomes progressively less dense towards the south and the north-west and the anomalies representing the streets become correspondingly fainter. 
Recent work by Norfolk County Council's Historic Environment Service, under the aegis of the English Heritage-sponsored National Mapping Programme, has also demonstrated that the town's streets are linked with an extraordinarily complex system of roads and trackways in the surrounding landscape, suggesting perhaps that, rather than being a town conceived with a grid plan at its inception, much of the urban plan of Caistor grew more organically over time. ${ }^{13}$ Nonetheless the dominant interpretation of Caistor's streets remains that of Donald Atkinson, which will now be considered.

\section{DONALD ATKINSON'S DATING OF THE STREET GRID}

The Flavian dating of Venta Icenorum was first suggested by Francis Haverfield who furnished a comprehensive description of the site in the Norfolk volume of The Victoria History of the Counties of England. ${ }^{14}$ This was the most authoritative account of Caistor published to that point, in which Haverfield dismissed previous suggestions that Caistor was a military site and suggested, based on the evidence of the coins from the site, that 'its Roman life commenced during the last twenty or thirty years of the first century'.

Haverfield's dating was followed by Atkinson who dated the street grid to 'about 70 A.D., when presumably the process of pacification which followed the revolt of Boudicca in 61 was complete'. ${ }^{15}$ The dating of the street grid to the 70s was repeated by Atkinson on a number of occasions, using almost identical language, with newspaper reports suggesting that this view was firmly established by 1930. It was repeated by Christopher Hawkes in his 1949 overview of the site (written in consultation with Atkinson) in which he wrote that '... the town will have been founded under the Roman policy of pacification after Boudicca's revolt had been suppressed'. ${ }^{16}$ The Flavian foundation of the town and the laying out of the streets in the $70 \mathrm{~s}$ in the immediate post-Boudican period has been repeated many times and remains canonical in much of the secondary literature on Roman Britain as well as literature on Boudica, Norfolk and the site itself (notwithstanding Vivien Swan's questioning of it in 1981 and Frere's acknowledgement that A.D. 70 is 'too early'). ${ }^{17}$

Despite the frequency with which Atkinson's dating has been repeated, there is in fact no compelling evidence for it. Indeed, all the evidence relating to the dating of the street grid from Atkinson's own excavations suggests that the streets are unlikely to be earlier than A.D. 90 and may well date to the second century. The evidence derives from Atkinson's investigations of the streets around Insula IX in the 1929 season and the excavation of the street immediately inside the South Gate of the town in 1934 (FIGS 8-9).

\section{THE EAST STREET}

Atkinson excavated two sections through the street to the east of the two temples in Insula IX. He identified eight successive layers of rammed gravel in the street, which had a pronounced camber, with a total thickness of $3 \mathrm{ft} 2$ ins in the centre. The camber was created at the lowest level by

13 Bales et al. 2010, 67-70.

14 Haverfield 1901.

15 Atkinson 1931, 133.

16 Hawkes 1949, 62.

17 Repetition of Atkinson's dating of the street grid can be found in literature on Roman Britain (e.g. Frere 1987, 99; Wacher 1995, 245; Mattingly 2006, 279), in literature on Boudica (e.g. Aldhouse Green 2006, 224; Sealy 1997, 56; Collingridge 2006, 274), and literature on Iron Age and Roman Norfolk and the site itself (e.g. Davies 2001, 12; 2009, 167; Robinson and Gregory 2003, 56). See Swan 1981 and Frere 2000, 354 for alternative views. 


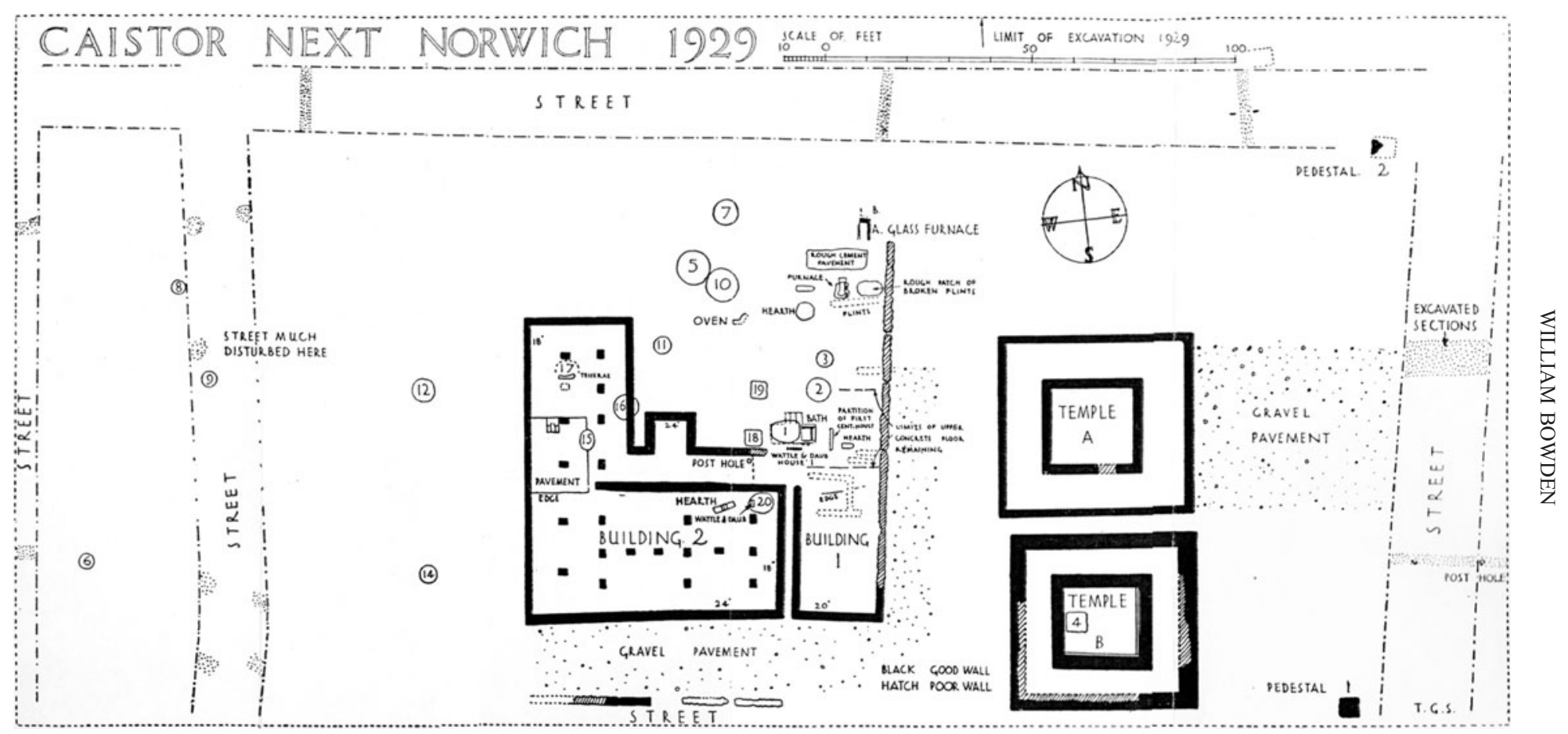

FIG. 8. Donald Atkinson's plan of Insula IX showing the location of excavated sections of streets. (From Atkinson 1931; by permission of the Norfolk and Norwich Archaeological Society) 


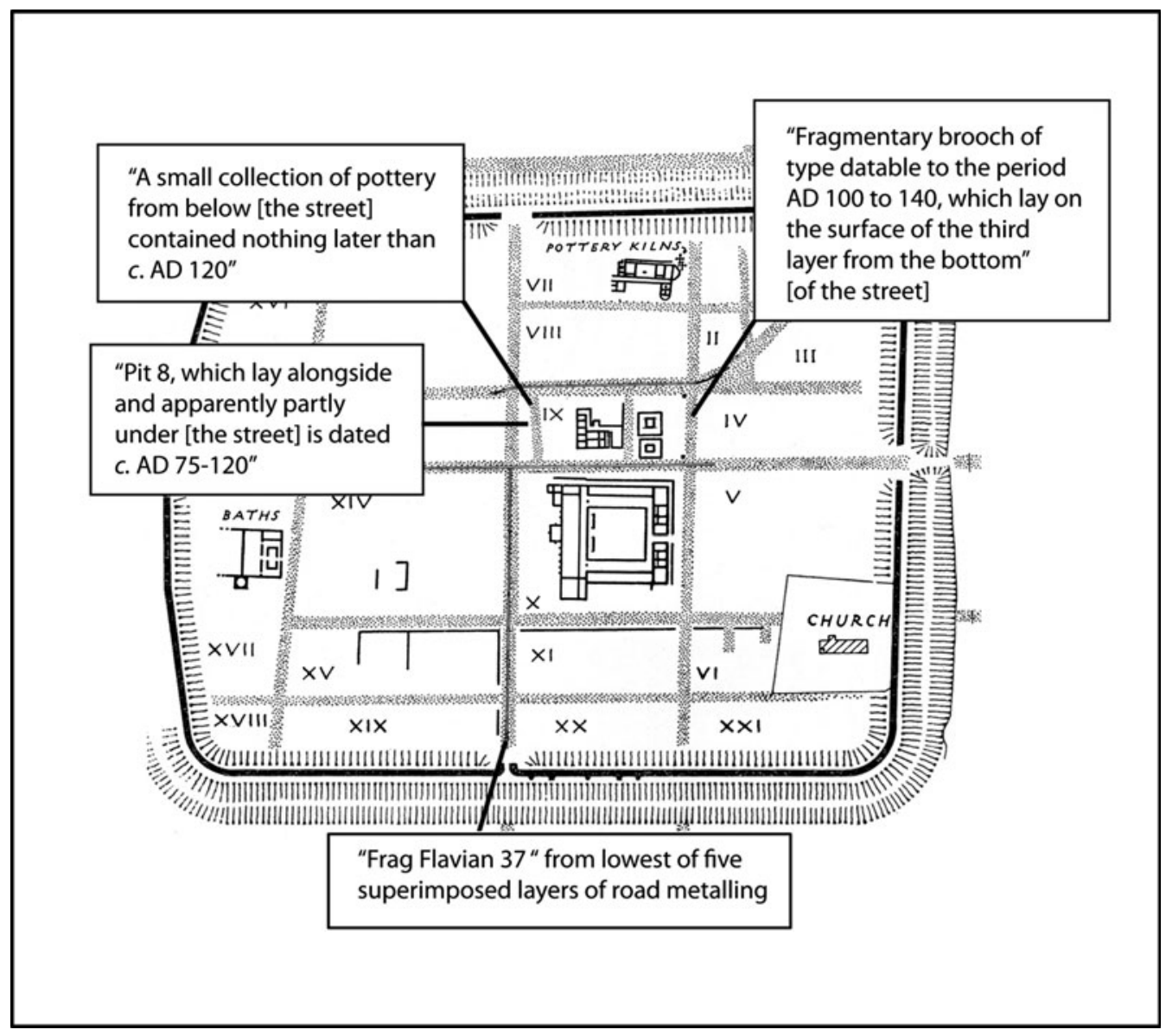

FIG. 9. The dating evidence for the streets from Donald Atkinson's excavations.

digging into the grey sand on each side, rather than through building up the centre of the road. The initial street was recorded as being $18 \mathrm{ft}$ wide, although from the third layer up the street expanded westwards to an overall width of $21 \mathrm{ft}$. The surfaces were separated by 'a thin film of grey sandy earth' which was interpreted as an accumulation of mud and dust through use. The upper levels were heavily 'penetrated by shallow pits and hollows'. The dating for this street (and indeed the entire street grid) rested on 'a fragmentary brooch of a type datable to the period A.D. 10040 , which lay on the surface of the third layer from the bottom'. ${ }^{18}$ This brooch can no longer be identified, but even if it could be, its position in the sequence renders it useless for determining the date at which the street was laid out.

\section{THE NORTH STREET}

Three sections were excavated through the street to the north of Insula IX. The depth of metalling varied slightly between the sections (respectively $2 \mathrm{ft} 4$ ins, $2 \mathrm{ft} 5$ ins and $2 \mathrm{ft} 2 \mathrm{ins}$ ), with five

18 Atkinson 1931, 96. 
layers recorded in the westernmost section and six layers in one of the others (which is not specified). The layers in some cases did not extend across the full width of the street, suggesting, according to Atkinson, patching rather than full resurfacing. The width was recorded as $17 \mathrm{ft}$, which remained constant throughout the life of the street. No dating evidence is recorded.

\section{THE WEST STREET}

Two sections were excavated through the West Street although they did not cross its full width. Its construction 'resembled the others', with a depth of metalling of $2 \mathrm{ft} 9$ ins at a point $5 \mathrm{ft}$ from its eastern edge. Atkinson suggested that it had 'about the same number of layers' as the East Street. No dating evidence is noted.

\section{THE STREET DIVIDING INSULA IX}

Atkinson also excavated a probable street 'thirty-six feet east of the west street', which bisected the western part of Insula IX. It lay on a 'stratum of disturbed soil' slightly over an inch thick and consisted of two layers of rammed gravel in total ' 4 ins to 6 ins thick and $16 \mathrm{ft}$ wide'. Atkinson describes the dating evidence as follows: 'A small collection of pottery from beneath it contained nothing later than c. 120 A.D. Pit 8, which lay alongside of it and apparently partly underneath it — but the pit was cleared before the street was recognised - is dated c. $75-120$ A.D., while Pit 9, containing material of c. 200 to 250 A.D., was dug through it.' 19

\section{THE STREET BY THE SOUTH GATE}

Other evidence for the streets comes from the 1934 excavations of the south gate, where Atkinson cut a section through the street just inside the town to the north of the gate. ${ }^{20}$ His lecture notes describe 'at least five different levels' of gravel, although this number is not clear from his notebooks. Their combined depth (as far as can be extrapolated from Atkinson's measurements) was a minimum of 26 ins. ${ }^{21} \mathrm{He}$ also indicates a layer of 'humus' 8 ins deep, beneath the lowest level of gravel, which may be a relic soil level. A ditch was noted on the eastern side of the road. His notebook records 'in bottom yellow road frag Flavian 37+ chip [?] 27', presumably referring to fragments of Dr 37 and 27 vessels from the lowest level of road metalling. Neither sherd can now be identified.

Atkinson suggested that only two of these layers predated the construction of the gate, in his lecture notes dating them respectively to the Flavian and Hadrianic periods. The reasoning for this dating is not clear (since the pottery is not mentioned), but it is possible that he was equating the surfaces to the periods of occupation that he identified in the 1929 excavations, the first two of which he placed respectively in the Flavian and Hadrianic periods. ${ }^{22}$

The dating of the road rests to some extent on the 'frag Flavian 37 ' noted above, which clearly only provides a terminus post quem. To use this evidence to place the road in the 70 s would require this to be an early example of Dr 37 that had been broken very early in its life and placed almost immediately in the road. This would be very atypical for Caistor where

Atkinson 1931, 97.

Collingwood and Taylor 1935, 213.

I am very grateful to Natasha Harlow who transcribed these lecture notes and whose work on the Atkinson archives has done much to shed light on the 1929-35 excavations.

22 Atkinson 1931, 130-1. 
preliminary analysis of the pottery suggests that samian tends to be very long lived. The presence of this Dr 37 fragment led Frere to suggest 'that the street may have been laid down c. A.D. 90-120, a date range that is consistent with other evidence for the establishment of this civitas capital'. ${ }^{23}$

\section{EVIDENCE FROM THE NEW EXCAVATIONS}

When the current Caistor project commenced in 2006, one of the stated objectives was to investigate the origins of the town. Given the unsatisfactory nature of Atkinson's dating of the street grid, it was clearly of fundamental importance to clarify when the streets were laid out and investigate whether they did reflect a unified urban project — the formal creation of a town. To this end, following the geophysical survey of the town, two sections of the street grid were selected for investigation. The first (excavated in 2010) examined the 'Diagonal Street' in the north-east of the town, while the second (excavated in 2011) examined the westernmost street in the walled area (see FIG. 7). The evidence from these excavations discussed here will be limited to that directly relating to the streets.

\section{THE DIAGONAL STREET}

One of Caistor's streets has always clearly stood out from the rest of the town plan, owing to the fact that it runs at an angle of approximately 45 degrees to the rest of the street grid. It starts from the crossroads at the northern junction of Frere's Insulae IX and IV and runs towards the north-east corner of the walled area. It commenced at what appears from the aerial photographs and geophysical survey to be a large, possibly metalled, precinct. The west side of this precinct is flanked by the two temples excavated by Donald Atkinson in 1929, while on the east side is a curving geophysical anomaly that we have tentatively interpreted as a theatre, an identification that is lent some support by its proximity to the temples. ${ }^{24}$

The road runs north-east out of the town towards a major extramural temple complex, entered via a monumental gateway through the west wall of the temple precinct. ${ }^{25}$ One function of the street, therefore, seems to have been to link two of Caistor's principal cult areas. Its function as a route between these two temple areas was rendered obsolete by the construction of the town wall, suggested by Frere to have occurred in the later third century, an issue returned to below. The striking angle of this road has led to suggestions that it predates the rest of the street grid, ${ }^{26}$ and indeed one reason for excavating a section through it, beyond extracting further dating evidence for the streets, was to test this hypothesis and to investigate whether, for example, it represented an Iron Age trackway.

The street was excavated in part of an L-shaped trench, which also investigated a substantial area to the south. The individual layers of road metalling were extremely hard, with the natural sand matrix combining with fine gravel to form a sort of natural concrete. The individual layers could be distinguished through the way they 'peeled' off the layer below, with individual layers sometimes separated by thin lenses of grit. It was not always clear, however, if the layers represented surfaces in their own right or whether some of them were make-up levels for a surface above (FIGS 10, 11 and 12).

Only half of the road was excavated down to the underlying natural sand (3229), although natural sand was reached at other points of the trench. The sand deposit beneath the road

Frere 2005, 311.

24 Bowden and Bescoby 2008, 332.

25 Gurney 1986.

26 e.g. Wacher 1995, 245. 


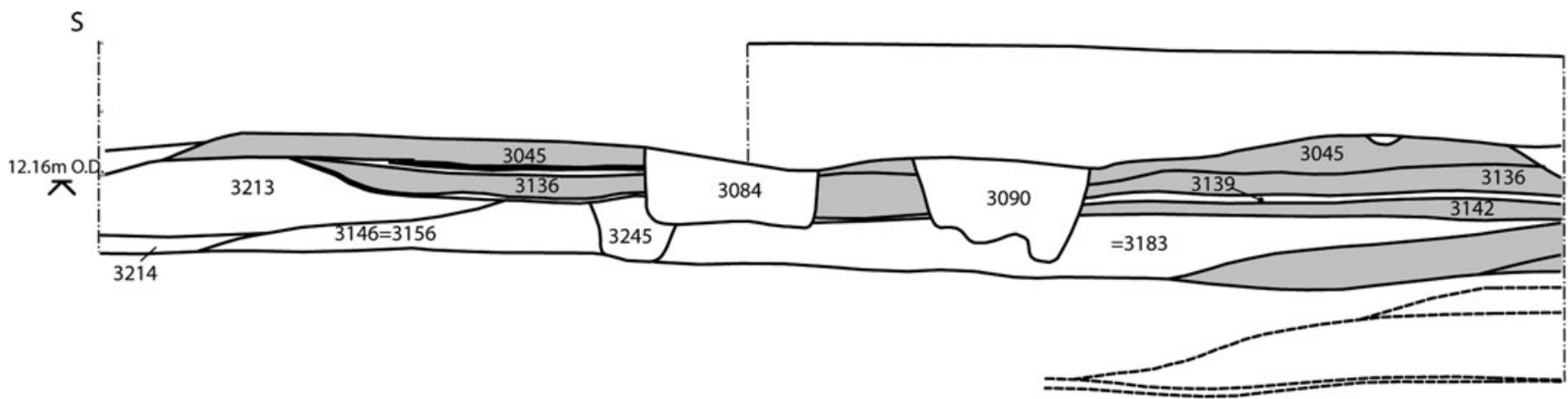

\section{1}
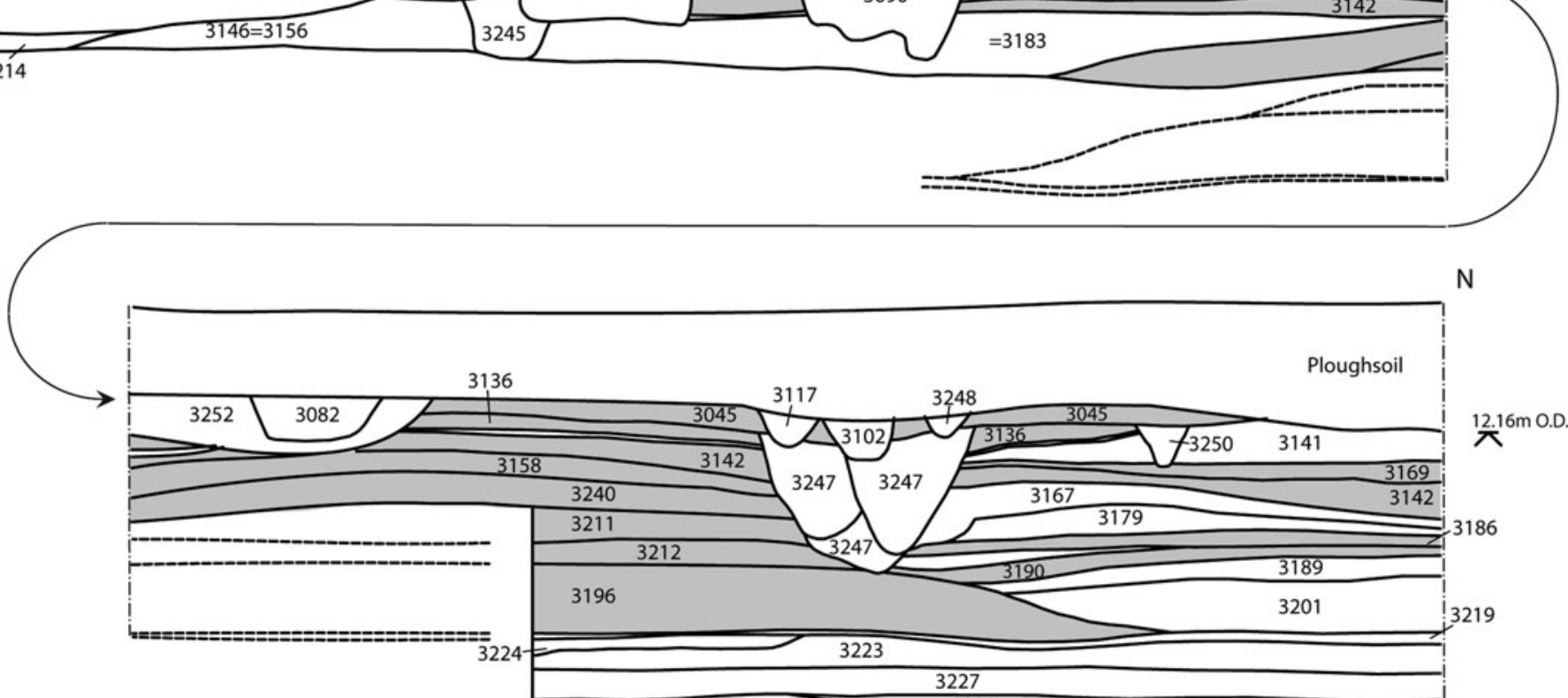

$\mathrm{N}$

Ploughsoil

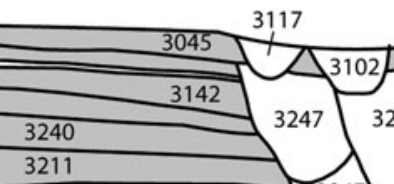

3248

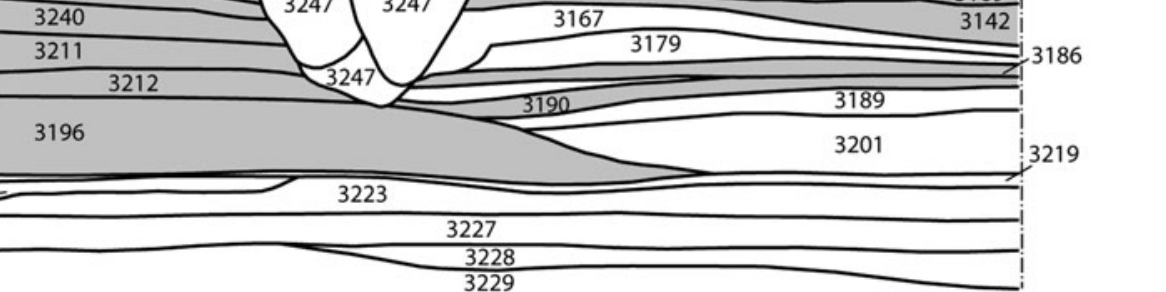

FIG. 10. North-east-facing section through the Diagonal Street. (Drawn by William Bowden and Giles Emery) 
(3223, 3227, 3228) contained a single sherd of a Sandy Oxidised Ware flagon probably dating to the second century (3228). ${ }^{27}$ Above this a layer of soft grey silty sand (3224) (recalling Atkinson's descriptions of the material under the roads around Insula IX) gave way to a thin spread of gravel (3219) which may have been preparation for construction of the road.

Above this gravel spread was the primary road layer (3196), composed of rammed flint pebbles $30-100 \mathrm{~mm}$ in diameter and rising in a pronounced camber to a maximum depth of $0.29 \mathrm{~m}$. The material used was noticeably coarser than the gravel layers above it and it is likely that it was an agger rather than being a surface in its own right. This was overlain by a surface (3212), $80 \mathrm{~mm}$ thick, made of finer flint pebbles (30-60 mm in diameter) which also contained a single sherd of a burnished Sandy Grey Ware jar or beaker unlikely to be much earlier than the mid-second century. Clearly, if this is the surface of the first phase of the road, this has implications for its dating, although, as with the single sherd from beneath the road, the evidence is too insubstantial to be entirely conclusive. This surface lay beneath a finer gravel surface (3211), $140 \mathrm{~mm}$ thick and made of rounded flint pebbles $(20-50 \mathrm{~mm}$ in diameter), which was interpreted as the second principal phase of road surfacing.

These surfaces were overlain by two further similar surfaces of fine rammed gravel (3240 and 3158), each c. $100 \mathrm{~mm}$ thick, the uppermost of which (3158) contained a single sherd of a Sandy Grey Ware dish dating from the mid-second to fourth century. These were apparently the latest surfaces that related to the primary cambered road, although the northern limit of the earlier phases of road was obscured by a series of deep ruts (3247) cutting through the later road surfaces above. Although the full width of the road was not revealed at its base, it was estimated to be at least $5.8 \mathrm{~m}$ across.

These initial phases of the cambered road were partially sealed beneath a thick olive brown silt layer that appeared both on the south side of the road $(3146,3156,3183)$ and on the north side (3189). These were rich organic deposits full of material dating to the late second and third centuries. On the north side of the road, one of these layers (3189) overlay a much more sterile silt deposit (3201) which probably represented silts washed from the road surface (discussed below). The latest material from these deposits on the north side of the road (3189) dated to the mid-third century or later, providing a terminus post quem for the later road surfaces above.

These silt deposits were overlain by a series of further gravel layers that represent a progressive widening of the road. This is a common feature in Roman towns where the 'road silts' that collected at the edges of streets were dealt with simply by metalling over them. On the north side of the road at Caistor, multiple layers of gravel $(3190,3186,3179,3167)$ are present above the road silts, perhaps representing an attempt to consolidate the ground and prevent subsidence (although two of the lower layers - 3186 and 3190 - may have been surfaces in their own right). Above these is a further layer of metalling $(3142=3169)$ which widened the road to at least $6.67 \mathrm{~m}$ (its full extent was not revealed on the northern side). This was followed by a further silt deposit (3141), in turn overlain by two much wider successive gravel surfaces (3136 and 3045) which brought the road to $9.37 \mathrm{~m}$ across. These two latest surfaces seem to represent a slight southwards shift in the alignment of the road. Both were pierced by a series of ruts (at least one of which was at a slight angle to the road), which seem to have been filled on a number of occasions.

The pottery sequence suggests that this progressive widening and shifting of the road took place between the mid-third and fourth centuries, with the last surface (3045) containing a sherd of Hadham Ware no earlier than the fourth century. Although the chance of intrusive finds is high owing to the rutting, the significant deposit of the mid-third century or later (3189) beneath this

\footnotetext{
27 Pottery from the excavations has been identified and catalogued by Alice Lyons, with samian identified and catalogued by Gwladys Monteil. Coins have been studied by Sam Moorhead.
} 


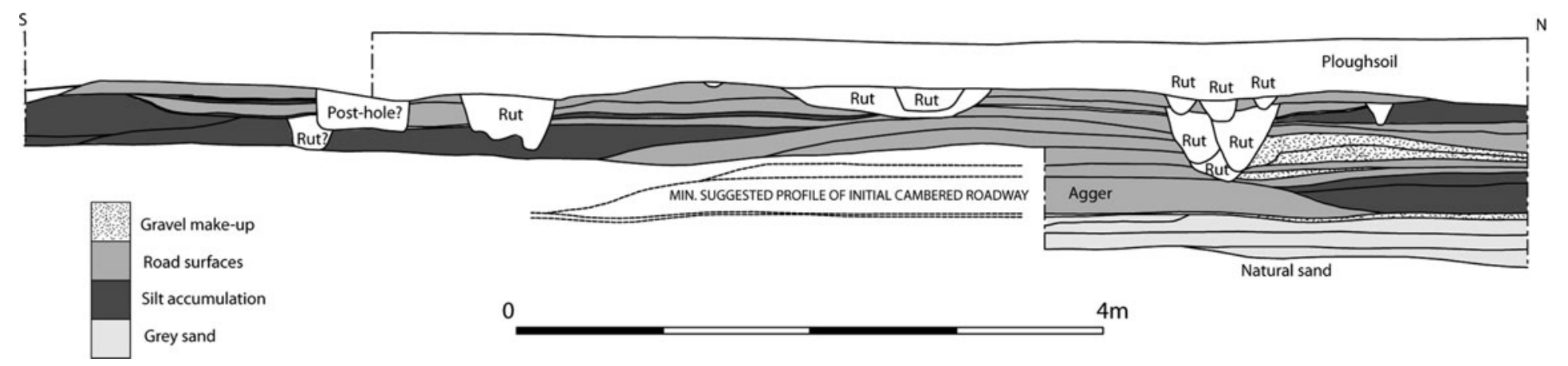

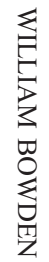

FIG. 11. Interpretative section showing overall profile of the Diagonal Street. (Drawn by William Bowden and Giles Emery) 


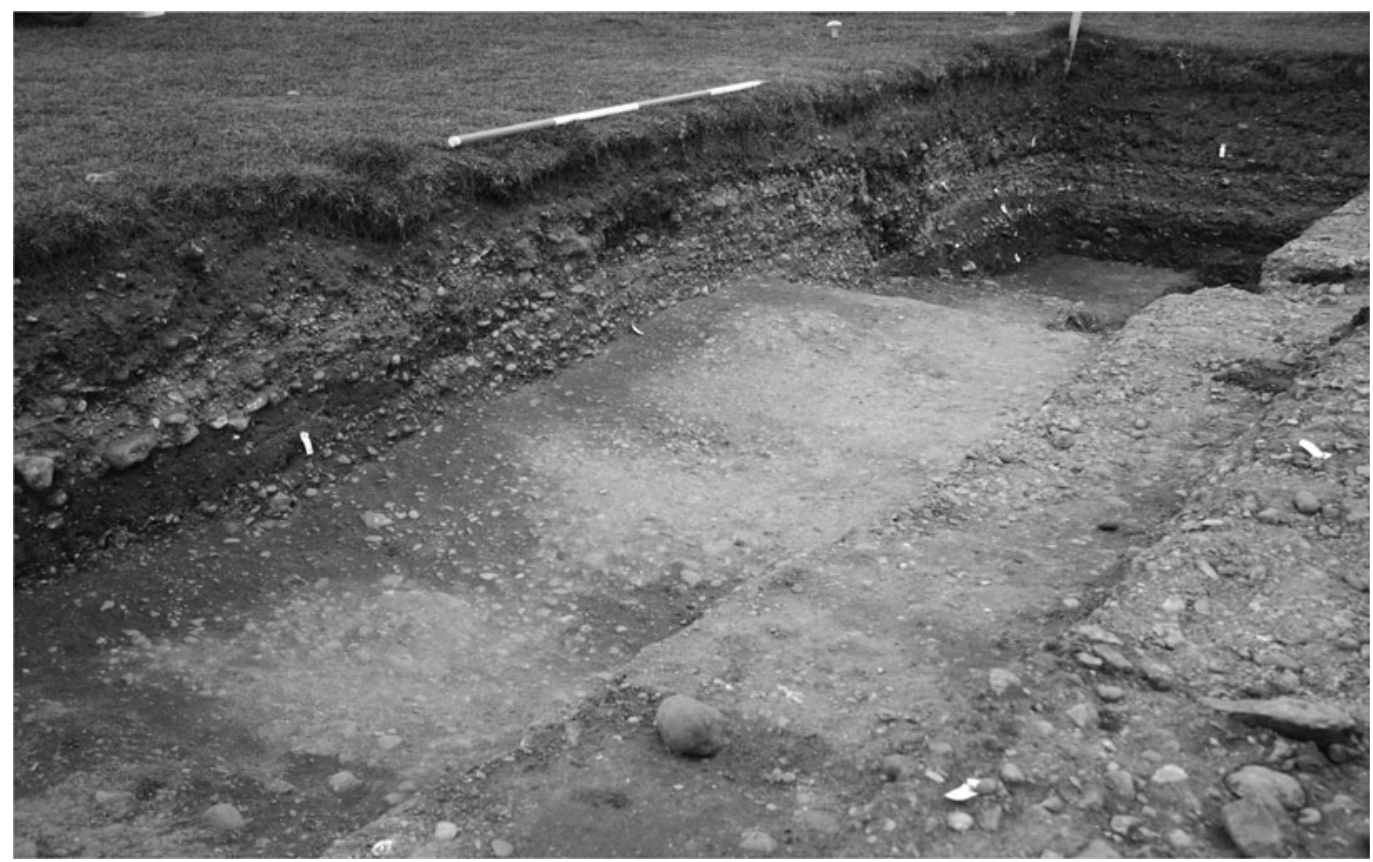

FIG. 12. View of the north-east-facing section through the Diagonal Street looking north-west. (Photo: William Bowden)

later series of surfaces provides a secure terminus post quem. In total eight layers of metalling were identified with a combined depth of $0.86 \mathrm{~m}$.

The sequence recovered from the Diagonal Street thus seems relatively clear. Although the evidence is limited, that which we do have indicates that the construction of the earliest metalled street took place in the second century. ${ }^{28}$ The sterile nature of the earliest road silt deposit suggests that the earliest road was running through an area that saw limited activity for at least part of the second century. At least two episodes of resurfacing had occurred by the mid-third century, as silts built up beside the road. These road silts have been recognised at other towns in Roman Britain, for example Cirencester and Canterbury. ${ }^{29}$ The explanation is that wear on the road and the passage of animals generated dust and dirt that was then washed to the sides by rain, causing the build-up of these deposits along the roadside. As the silt deposits grew and crept back over the road, the simplest solution was to lay a new surface, leading to the progressive widening of the road, which certainly happened at Caistor. A similar widening of the street was noted by Atkinson at the East Street discussed above.

The date of the uppermost surfaces in the later third and fourth centuries is significant in that the construction of the wall circuit rendered the street obsolete as a major route out of the town, since the wall blocked the street $c .50 \mathrm{~m}$ from the excavated section. It seems unlikely that a backstreet would have warranted maintaining as a road over $9 \mathrm{~m}$ wide, thus adding some circumstantial evidence for the construction date of the walls. Frere placed the walls around A.D. 275-80,

28 Evidence from elsewhere in the trench suggests little or no activity in this area of the town before the mid-second century.

29 Holbrook and Pamment Salvatore 1998, 22-3 (Cirencester); Blockley et al. 1995, 150-75 (Canterbury). 
contra Atkinson who suggested a date of around A.D. 200. The evidence of street maintenance into the fourth century certainly supports a late date of construction for the walls, possibly even later than that suggested by Frere. We should note, however, that the geophysical survey seems to show the Diagonal Street curving round at the junction where it meets the north-south street immediately inside the corner of the walled circuit. The curving junction between the two streets appears to be extremely wide, perhaps to accommodate vehicles forced to negotiate the sharp turn caused by the blocking of the Diagonal Street.

\section{THE NORTH-WEST STREET}

The second section sampling the street grid was excavated through the westernmost street within the walled area, $c .40 \mathrm{~m}$ south of the north wall (see FIG. 7). The reason for excavating here was to sample the street at a point where it was seemingly cut by a possible post-Roman gulley. The trench did not cover the full width of the road, but investigated an area 6 by $4 \mathrm{~m}$ covering the eastern half of the road and a series of features along its eastern edge. Although a large wheel-rut that cut through much of the sequence meant the chance of intrusive finds was present, the sequence as a whole is fairly clear (FIGS 13-14).

The earliest stratified deposits lay above a disturbance in the natural probably caused by a large tree, associated with flint flakes of Mesolithic-Neolithic date. Immediately above this lay a thin deposit of dirty sand (4857) which produced 48 sherds of pottery, of which 26 sherds were Sandy Grey Ware with a possible date range of the second to fourth centuries. The most closely dated sherd was a piece of Nene Valley Colour Coated ware of late second- to third-century date. This deposit formed the bottom of what the excavators interpreted as an unmetalled track, in which traffic had created a slight hollow-way, with signs of wheel-ruts present. A deposit within this hollow track (4860) contained a sherd of Dr 31 dating to A.D. 140-200 as well as possible mid-third-century material. The track was subsequently formalised with a metalled surface (4843) with a gravel make-up layer beneath (4851), both deposits having a total depth of no more than $180 \mathrm{~mm}$. The metalling contained a single sherd of late second- to third-century pottery.

Following a period of use indicated by wheel-ruts, the road was resurfaced with a second layer of metalling (4815), which had a maximum depth of $80 \mathrm{~mm}$. This was subsequently truncated along its eastern edge by a series of pits or post-holes, the fills of which contained material with a date range of the mid-third to fourth centuries. These dated pits appear to respect the eastern edge of the road although the road surface was also cut by a well-defined post-hole, but this could not be closely dated.

The sequence identified thus suggests that this part of the street grid started as an unmetalled track in the late second century before it was formalised with a gravel surface. It subsequently saw one episode of repair giving a total depth of road metalling of $260 \mathrm{~mm}$, in marked contrast to the other streets described above (recalling instead the smaller street excavated by Atkinson that sub-divided Insula IX). Like the Diagonal Street it would have been turned into a cul de sac by the construction of the fortifications, although the later pits seem to have respected its alignment. There can be no doubt that this street is of a later date than the others described above and cannot be seen as part of an original street grid or urban plan.

\section{DISCUSSION}

The evidence for the street grid at Caistor, although variable in its quantity and quality, clearly does not support the idea that a gridded town plan was laid out as part of a unified urban design in the A.D. 70s. Donald Atkinson's dating, despite the frequency with which it has been 

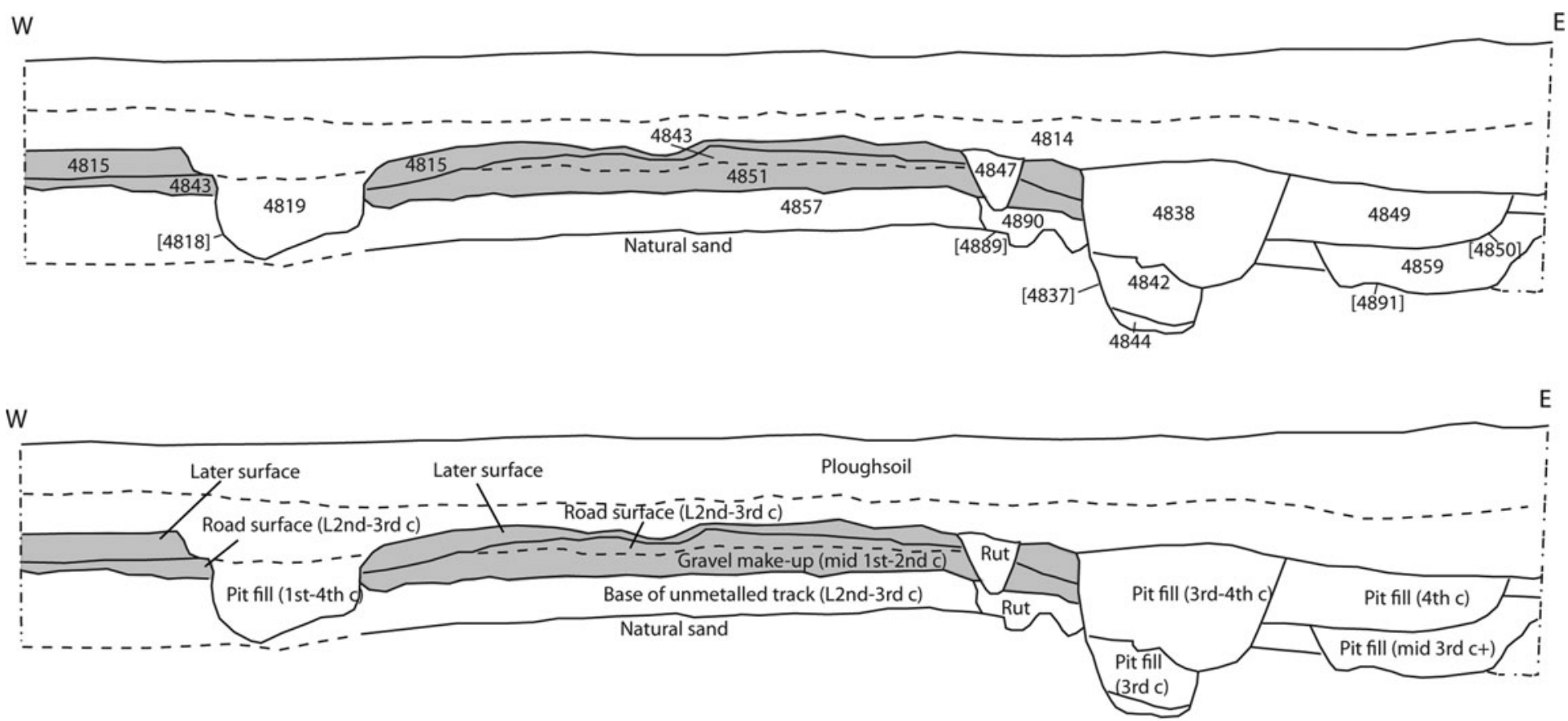

FIG. 13. South-facing section of the North-West Street. Interpretation shows date ranges of pottery present in each level. (Drawn by William Bowden) 


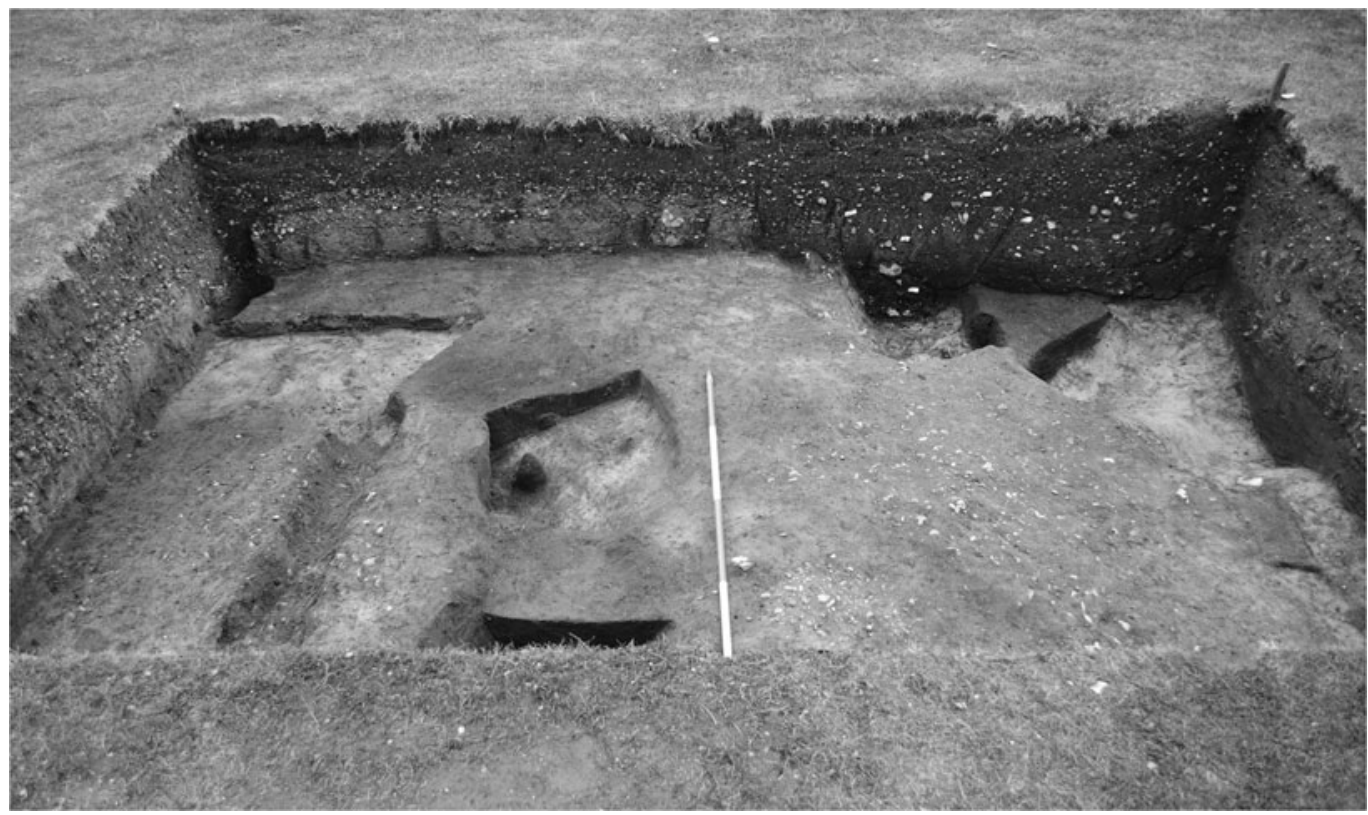

FIG. 14. View of south-facing section of the North-West Street. (Photo: Giles Emery)

repeated, rested on the fragment of brooch datable to A.D. 100-40 found on the surface of the third layer of gravel in the East Street (bearing in mind that he arrived at this dating several years before his excavations of the South Gate). None of the evidence from Atkinson's excavations in fact suggests a date as early as A.D. 70. The evidence from the South Gate suggests, following Frere, that this particular section is unlikely to be earlier than A.D. 90-120.

This evidence combined with that from the recent excavations suggests it is much more likely that the earliest metalled streets were laid out at some point in the second century, probably during its first half. We know that at least one of the main streets of the grid (the North-West Street) was not formalised until the late second century at the earliest and so it can reasonably be argued that the street plan developed more gradually. Consequently the earliest lay-out of the town was smaller than that covered by the streets at their greatest extent.

The idea of a more gradual development may be reflected in the variations in the number of metalled surfaces present. These vary between two (in the North-West Street and the secondary street excavated by Atkinson in Insula IX), five (in the street by the South Gate and in the North Street) and eight (in the Diagonal Street and the East Street). Variations in the strength of the anomalies identified by the geophysical survey of the town also indicate that some streets have a much greater depth of metalling than others.

The fact that only five layers of metalling were recorded in the street by the South Gate is intriguing. The position of this section on what was apparently the main north-south axial street and by the (later) South Gate would presumably make it susceptible to heavy wear, so the fact that it saw less repair than the streets in the centre and north-east of the town implies that it was later in date or that the southern approach to the town did not see as much traffic as other areas. The latter may well be the case since the principal entrance to the town seems to have been from the west. However, the fact that only two of these surfaces apparently predate 
the construction of the gate (probably c. A.D. 275-80) could support the idea that this section of road was metalled later than those in the centre of the town. ${ }^{30}$

The relationship between this section of road and the West Street, which ostensibly forms part of the same axial street, is also of interest. Although the West Street was not investigated in detail, it seems that the section excavated by Insula IX had a greater number of surfaces than the section by the South Gate. Again this indicates that the section by the South Gate was either later in date, repaired more infrequently, or that the West Street section remained in use for longer. The geophysics plot is also of relevance in this respect in that it shows the alignment of this axial street shifting with different sections producing anomalies of different widths.

Variations in the number of surfaces present in different streets were also noted at Cirencester, although in almost all cases the Cirencester streets had a greater number of surfaces than those at Caistor, varying from a minimum of nine surfaces to a maximum of twenty-four at a point along Ermine Street (which formed the cardo maximus of the town), the latter having a depth of $3 \mathrm{~m}$. The surfaces of the Cirencester streets were also found sometimes to be in pristine condition, as was noted at the Diagonal Street at Caistor. Based on the number of surfaces at Cirencester it has been estimated that resurfacing occurred at intervals of between 15 and 39 years. ${ }^{31}$ If is is assumed that the gravel surfaces at Cirencester and Caistor were similarly durable, the much smaller number of surfaces noted at Caistor suggests either that the streets at the latter were significantly later in date, or that the streets saw less use or were less well-maintained, all of which suggest intriguing scenarios.

A view of Caistor which sees its street grid developing incrementally during the second century is certainly comparable with the picture emerging from other towns in Roman Britain. Richard Brewer's excavations at Caerwent have suggested that the street grid did not reach its full form until the late second century at the earliest. ${ }^{32}$ Similarly at Cirencester, although dating evidence is poor, there are indications that the street grid developed well into the second century, perhaps around a core of four insulae that later contained the town's major public buildings. ${ }^{33}$ A comparable picture has emerged at Leicester where the earliest metalled street surfaces date to the first half of the second century, although the insulae may have been laid out previously as a system of unmetalled tracks and ditches. ${ }^{34}$ At Canterbury it is also now thought that much of the street grid is later than previously believed, dating perhaps to the very late first or early second centuries, with the streets uncovered in the Marlowe car park excavations dating to around A.D. 100. ${ }^{35}$ The earliest elements of the street grid at Carmarthen meanwhile seemingly date to the early to mid-second century. ${ }^{36}$

The evidence of the street grid suggests that the long-standing idea of the formal establishment of the town as part of the Roman response to the Boudican revolt is no longer tenable. Although there is certainly evidence of activity at Caistor during the Flavian period, there is little evidence for a settlement of significant size or with a formal street grid prior to the second century A.D. ${ }^{37}$ None of the nine trenches excavated under the aegis of the current project have identified stratified deposits earlier than the second century A.D.

The fact that the street grid (whatever its initial extent) may not have been laid out until several decades after the revolt means that the urban infrastructure cannot be associated with the

30 As noted above Frere dated the walls to A.D. 275-80 (Frere 2005, 324-5). Atkinson argued for a date of A.D. 200 (Collingwood and Taylor 1935, 213).

31 Holbrook and Pamment Salvatore 1998, 22-3.

32 Brewer 1993, 59.

33 Holbrook and Pamment Salvatore 1998, 22-3.

34 Connor and Buckley 1999, 27.

35 Blockley et al. 1995, 85-6.

36 James 2003, 87-8.

37 The evidence for first-century activity at Caistor is discussed in greater detail in Bowden forthcoming. 
'pacification' of the Iceni. We must ask, therefore, why Atkinson was so adamant that Caistor was part of a policy of pacification towards the Iceni following the revolt.

The Boudican revolt was certainly increasingly in the minds of archaeologists during the late $1920 \mathrm{~s}$, at a time when the physical evidence for the impact of the rebellion was being uncovered, notably at Colchester, where in 1927 the so-called First and Second Pottery Shops were discovered and 1928 saw the recovery of the tombstone of Longinus Sdapeze, which was thought to have been damaged by the rebels. ${ }^{38}$ Atkinson would certainly have been aware of these discoveries, which may have contributed to his placing Caistor within a Boudican context. Certainly the dating of the street grid to A.D. 70 can be ascribed to his willingness to see the town as part of the Roman response to the revolt, although it is also possible that he was influenced by Haverfield's interpretation of the coin evidence (noted above), which also suggested an early Flavian date. Haverfield's dating was certainly noted by Ernest Kent in his commentary on the 1928 aerial photograph, in which it is proposed that 'the evidence of its coins suggests that its corporate life began a few years after the defeat of Queen Boudicca in A.D. 61'.39 Atkinson provided an afterword to Kent's paper, and it is likely that the post-Boudican foundation date of the town was in his mind before he started excavation.

Atkinson's perception of the relationship between Rome and the native populations of Britain was very much of its time. As Richard Hingley and others have shown, in Britain during the late nineteenth and early twentieth centuries there was an increasing emphasis on the civilising and moral purpose of the Roman Empire, reflecting greater concerns with these aspects of the British Empire. ${ }^{40}$ Although the most oft-cited example of this is Haverfield's The Romanization of Roman Britain (1915), Haverfield had previously expounded his ideas on the civilising influence of Rome in his description of Roman Norfolk in the Victoria County Histories in which he placed Caistor and Romano-British Norfolk into the wider context of Roman Britain, a province that he considered 'became Romanised later and less perfectly than the rest'. In his discussion of Roman Norfolk, Haverfield also advanced the notion that 'Celtic tribal centres ... grew into towns under the influence of Roman civilization', a view that was subsequently reflected in Atkinson's own interpretation of Caistor. ${ }^{41}$

This idea of a progressive civilising Roman influence is clearly articulated in Atkinson's descriptions of his own discoveries. For example, the structural sequences encountered in the 1929 excavations 'show a consistent development which indicates the gradual adoption of building methods alien to the native Celts' ${ }^{42}$ However, for Atkinson the excavations ultimately demonstrated 'the conservative character of the Iceni and the relatively imperfect degree of Romanisation to which they attained', the last line echoing Haverfield's description noted above. ${ }^{43}$ His insistence that the street grid was established in the aftermath of the Boudican revolt can be best understood in the context of this narrative of civilisation versus barbarism.

If the idea that the street grid was laid out in its entirety in the A.D. 70 s is discounted in favour of a view of the town that sees a more gradual development of the streets during the second century, this also closes the chronological gap between the layout of the streets and the construction of further public buildings such as the forum that has provided a cornerstone in theories regarding the post-Boudican impoverishment of the Iceni. The idea that the Iceni and Venta Icenorum 'lagged behind' the rest of Roman Britain, owing to the depredations suffered by the tribe following the Boudican revolt can again be traced back at least to Haverfield, who noted

\footnotetext{
38 The archaeological evidence for the Boudican revolt is usefully summarised in Hingley and Unwin 2005 (178-9 on the Colchester pottery shops).

39 Kent 1930, 281.

40 Freeman 1991; Hingley 1991; 2000, 114-28; 2008, 313-25.

41 Haverfield 1901, 281-2.

42 Atkinson 1931, 128-9.

43 Atkinson 1932, 42.
} 
(following Tacitus) that 'fire, sword and famine went through the lands of the insurgents' adding that 'it may well be that this devastation helped to produce that infrequency of Romano-British life that characterised the Icenian districts in later days'. ${ }^{44}$

This view subsequently became widespread. Frere noted that 'the civitas of the Iceni is usually considered to have lacked wealth at least during the first half-century following the Boudiccan rebellion' ${ }^{45}$ while Wacher notes that 'the provision of streets seems to have been the only major development during the Flavian period, presumably because the Iceni were too impoverished to pay for large public buildings'. ${ }^{46}$ As Swan demonstrated, this perception of the retardation of development in the territory of the Iceni also had serious implications for the dating of pottery in the region. ${ }^{47}$

It is perfectly possible that the aftermath of the revolt did have a negative effect on the territory of the Iceni. Tacitus stated that 'whatever tribes still wavered or were hostile were ravaged with fire and sword', continuing that 'nothing however distressed the enemy so much as famine, for they had been careless about sowing corn, people of every age having gone to the war, while they reckoned on our supplies as their own'. ${ }^{48}$ However, the evidence from Caistor does not particularly support such an interpretation, since in fact the town's development follows a trajectory similar to many others in Roman Britain and suggestions of impoverishment cannot be used uncritically to explain the appearance of the town. Although the town is small, rather than implying 'a meagre territory and a weak and small local elite' owing to the revolt as Mattingly suggests, we could see its limited size and lack of public buildings as instead representing an active rejection of the urban form. ${ }^{49}$ It is quite reasonable to argue that, rather than not being in a position to afford public buildings, the Iceni simply were not very interested in them.

The evidence of Caistor's street grid shows us that to understand the Iceni and Caistor during the Roman period the evidence must be extracted from the grip of the pervasive narratives that shaped study of the site throughout the twentieth century. As study of Caistor and the Iceni advances in the twenty-first century, we should endeavour to re-evaluate many of our preconceived notions regarding Rome and the Iceni, a relationship that is still too often viewed through the prism of the Boudican revolt.

\section{ACKNOWLEDGEMENTS}

The Caistor project represents a partnership between the University of Nottingham, the Norfolk Archaeological Trust (who own the site), South Norfolk Council (who manage the site), Norfolk County Council's Historic Environment Service and Norfolk Museums Service. I am very grateful to the Norfolk Archaeological Trust and its director, Peter Wade-Martins, who have both allowed and encouraged the work at Caistor, while David Gurney (NCC Historic Environment Service), John Davies (Norfolk Museums Service) and Will Fletcher (English Heritage) have provided encouragement, advice and practical support. The project is supported by the British Academy, South Norfolk Council, South Norfolk Alliance, Mr Michael Salter, Foyle Foundation, Roman Research Trust, Society for the Promotion of Roman Studies, John Jarrold Trust, May Gurney Ltd and A-Plant. This report is particularly dependent on the dating evidence provided by Alice Lyons (pottery), Gwladys Monteil (samian) and Sam Moorhead (coins) and the geophysical work of David Bescoby. Finally the project would not be possible without the enthusiasm and efforts of the excavation supervisors and the many participating volunteers.

44 Haverfield 1901, 286.

45 Frere $1971,15$.

46 Wacher 1995, 245

47 Atkinson 1932, 29; see also Swan 1981, 123-4.

48 Tacitus, Ann. 14.38.

49 Mattingly 2006, 384-5. See Bowden forthcoming for more detailed discussion of this issue. 
Department of Archaeology, University of Nottingham

will.bowden@nottingham.ac.uk

\section{BIBLIOGRAPHY}

Aldhouse Green, M. 2006: Boudica Britannia, Harlow

Arderon, W. 1749: 'A letter from Mr. Henry Baker, F.R.S. to the President, containing an extract of a letter from Mr William Arderon, F.R.S. to Mr. Baker, giving an account of the present condition of the Roman Camp at Castor in Norfolk', Philosophical Transactions 48, 196-203

Atkinson, D. 1931: 'Caistor excavations, 1929', Norfolk Archaeology 24, 93-139

Atkinson, D. 1932: 'Three Caistor pottery kilns', Journal of Roman Studies 22, 33-46

Atkinson, D. 1937: 'Roman pottery from Caistor-next-Norwich', Norfolk Archaeology 26, 197-230

Bales, E., Cattermole, A., Horlock, S., and Tremlett, S. 2010: The Archaeology of Norwich 'Growth Point' and Environs: Results of the Norwich Growth Point National Mapping Programme (NMP) Project (English Heritage Project no. 5313), Norfolk Historic Environment Service/English Heritage

Bescoby, D., Bowden, W., and Chroston, P.N. 2009: 'Magnetic survey at Venta Icenorum, Caistor St Edmund: survey strategies and initial results', Archaeological Prospection 16.4, 287-91

Blockley, K., Blockley, M., Blockley, P., Frere, S.S., and Stow, S., 1995: Excavations in the Marlowe Car Park and Surrounding Areas, Archaeology of Canterbury 5, Canterbury

Bowden, W. forthcoming: 'Townscape and identity at Caistor-by-Norwich'

Bowden, W., and Bescoby, D. 2008: 'The plan of Venta Icenorum (Caistor-by-Norwich): interpreting a new geophysical survey', Journal of Roman Archaeology 21, 325-34

Brewer, R.J. 1993: 'Venta Silurum: a civitas capital', in S.J. Greep (ed.), Roman Towns: The Wheeler Inheritance. A Review of 50 Years' Research, CBA Research Report 93, York, 56-65

Collingridge, V. 2006: Boudica, London

Collingwood, R.G., and Taylor, M.V. 1935: 'Roman Britain in 1934', Journal of Roman Studies 25, 213

Connor, A., and Buckley, R. 1999: Roman and Medieval Occupation in Causeway Lane, Leicester, Leicester Archaeology Monograph 5, Leicester

Davies, J.A. 2001: Venta Icenorum. Caistor St Edmund Roman Town, Norwich

Davies, J.A. 2009: The Land of Boudica: Prehistoric and Roman Norfolk, Oxford

Freeman, P. 1991: 'British imperialism and the Roman Empire', in Webster and Cooper 1991, 19-34

Frere, S.S. 1971: 'The forum and baths at Caistor by Norwich', Britannia 2, 1-26

Frere, S.S. 1987: Britannia: A History of Roman Britain, London

Frere, S.S. 2000: 'A limitatio of Icenian territory', Britannia 31, 350-5

Frere, S.S. 2005: 'The south gate and defences of Venta Icenorum: Professor Atkinson's excavations, 1930 and 1934', Britannia 36, 311-27

Gurney, D.A. 1986: 'A Romano-Celtic temple site at Caistor St Edmund', in A.K. Gregory and D.A. Gurney, Excavations at Thornham, Warham, Wighton and Caistor St Edmund, East Anglian Archaeology 30, Dereham, 37-58

Haverfield, F. 1901: 'Romano-British Norfolk', in H.A. Doubleday (ed.), The Victoria History of the County of Norfolk, Volume 1, Woodbridge, 279-323

Haverfield, F. 1915: The Romanization of Roman Britain, Oxford

Hawkes, C.F.C. 1949: 'Caistor-by-Norwich: the Roman town of Venta Icenorum', Archaeological Journal $106,62-5$

Hingley, R. 1991: 'The "legacy" of Rome: the rise, decline and fall of the theory of Romanization', in Webster and Cooper 1991, 35-48

Hingley, R. 2000: Roman Officers and English Gentlemen: The Imperial Origins of Roman Archaeology, London

Hingley, R. 2008: The Recovery of Roman Britain 1586-1906: A Colony so Fertile, Oxford

Hingley, R., and Unwin, C. 2005: Boudica: Iron Age Warrior Queen, London/New York

Holbrook, N., and Pamment Salvatore, J. 1998: 'The street system', in N. Holbrook (ed.), Cirencester: The Roman Town Defences, Public Buildings and Shops, Cirencester Excavations 5, Cirencester, 19-34

James, H. 2003: Roman Carmarthen. Excavations 1978-1993, Britannia Monograph 20, London 
Kent, E.A. 1930: 'The Roman fortified town of Caistor-next-Norwich', Norfolk Archaeology 23, 269-84

Leng, F.J. 1967: Tudor Historical Thought (reprinted 2004), Toronto

Mattingly, D.J. 2006: An Imperial Possession: Britain in the Roman Empire, London

Rivet, A.L.F., and Smith, C. 1979: The Place Names of Roman Britain, London

Robinson, B., and Gregory, T. 2003: Celtic Fire and Roman Rule, Cromer

Sealy, P. 1997: The Boudican Revolt Against Rome, Princes Risborough

Swan, V.G. 1981: 'Caistor-by-Norwich reconsidered and the dating of Romano-British pottery in East Anglia', in A.C. Anderson and A.S. Anderson (eds), Roman Pottery Research in Britain and North-West Europe, BAR International Series S123, i, Oxford, 123-55

Wacher, J. 1974: The Towns of Roman Britain (1st edn), London

Wacher, J. 1995: The Towns of Roman Britain (2nd edn), London

Webster, J., and Cooper, N. (eds) 1991: Roman Imperialism: Post-Colonial Perspectives, Leicester Archaeology Monograph 3, Leicester

Wheeler, R.E.M. 1929: 'Caistor and a comment', Antiquity 3.10, 182-7

Wilkins, W. 1796: 'An essay towards a history of the Venta Icenorum of the Romans and of Norwich castle; with remarks on the architecture of the Anglo-Saxons and Normans', Archaeologia 12, 132-80

Wilson, D.R. 2003: 'Air-photography and Venta Icenorum', in P. Wilson (ed.), The Archaeology of Roman Towns. Studies in Honour of John S. Wacher, Oxford, 251-7 